\title{
MANIFESTATION OF STRESS AND COPING CONCERNING PROFESSIONAL EXPERIENCE
}

\author{
Daiva Alifanoviene \\ Odeta Sapelyte \\ Siauliai University, Lithuania \\ Rita Orska \\ Rezekne Higher Education Institution, Latvia
}

\begin{abstract}
The paper focuses on the stress and coping exercised by pedagogues at mainstream schools in Lithuania. The main goal of the paper was to reveal significant contrast in manifestation of coping among different actors of educational process with regard to the diversity of their professional experience and spheres of activities. Quantitative empirical data were analysed by using descriptive and nonparametric statistical analysis (MannWhitney, Kruskall-Wallis tests). The empirical data $(N=478)$ has shown that specialists of educational support tend to apply avoidance-oriented strategies with retreat more often than subject teachers. In addition, stress coping techniques applied by pedagogues are discussed with regard to their professional qualification.
\end{abstract}

Keywords: Stress, coping, pedagogues, specialists of educational support; professional experience and qualification.

\section{Introduction}

Stress (stress en., cmpecc rus. - strain, tension) is considered as psychological and physical strain or tension generated by physical, emotional, social, economic, or occupational circumstances, events (Colman, 2015). It may be defined as interaction between a person and the environment when environmental impact is regarded as a threat to inner coherence and welfare of a person as well as one's psychophysical balance. The notion of stress is applied to depict physical and psychological anxiety, i.e. a situation with rising physical and emotional tension and incapability to cope with problems encountered when customary behavioural patterns are insufficient and new situation management strategies cannot be initiated efficiently (Bandziene, 2009; Gostautas, 1999; Pikunas \& Palujanskiene, 2005).

Nine out of ten Lithuanian inhabitants occasionally suffer from physical or psychological tension whereas every fifth Lithuanian claims to suffer from stress rather frequently. Recently, this phenomenon has become rather common and requires certain actions as it disturbs daily routine of a person considerably and 
affects efficiency of work. The majority of the interviewed (90\%) indicated that they encounter stressful situation from time to time and almost half of the respondents $(45 \%)$ stated that this happens mostly at work or educational environment. The analysis of the research has revealed that the level of stress and anxiety experienced by Lithuanians indicates the seriousness of the situation human resources is facing now (European Foundation for the Improvement of Living and Working Conditions, 2010; Keturakis, 1998).

The analysis of the data has shown that stress is most frequently experienced by the employees working in the following fields: public services, creative industries (artists, actors, writers), system of education (teachers, social workers) as well as those rendering foster and care services. Persons whose work involves human interaction (including teachers, pedagogues and specialists of educational support) obviously encounter rather stressful and tensed situations. Stress experienced by pedagogues is defined as high level stress; moreover, from $31 \%$ to $37 \%$ of the pedagogues living in the Baltic States suffer from it and this exceeds the common average of professional stress undergone by European pedagogues by 22\% (Report of European Trade Union Committee for Education, ETUCE, 2011). The researchers state that undergone stress affects health of pedagogues and lessens their job satisfaction. Stress on the institutional level may be caused by unsafe working environment and responsibility they bear for the children (Bandziene, 2009; Bulotaite \& Lepeskiene, 2006; Kepalaite, 2013a; Alifanoviene \& Vaitkeviciene, 2012); whereas publicly most often teachers suffer from lack of prestige, insufficient payment, unsafe working position and rivalry among schools including "bossimposed" precipitate reforms (Bubeliene \& Merkys, 2012, p.107).

Stress experienced by professionals has been investigated by scientists from different fields such as pedagogics, psychology, biomedicine or management. Due to new technologies of information and communication as well as intense way of life in all spheres (including educational system) dramatic changes of events have emerged. The reorganization of Lithuanian educational system throughout the last decade has introduced many changes, uncertainty, anxiety, frustration and stress which can hardly be counterbalanced by social welfare among the participants of the educational processes. Researchers (Bulotaite \& Lepeskiene, 2006, Bulotaite, Pociute, \& Bliumas, 2008; Kepalaite 2013a, 2013b; Alifanoviene \& Vaitkeviciene, 2012) have noted that educators suffer from professional stress rather frequently as they often have to encounter unforeseen circumstances and address them properly. In the context of social change and educational reforms, educators have to work under pressure of constant instability (Klizas \& Sulniene, 2012), which as well as perpetual challenging affects working results, quality and efficiency of professional educators. 
In the context of social tension, the analysis of stress as a notion, its peculiarities and management strategies has gained their relevancy (Grakauskas, 2004; Grakauskas \& Valickas, 2006; Valickas, Grakauskas, \& Zelviene, 2010). Despite the interest in manifestation of professional stress and its management strategies studied by various researchers, the analysis of stress experienced by Lithuanian educators have not encountered a proper investigation yet and the following questions have not been answered: how do pedagogues and specialists of educational support manage stressful situations? What circumstances cause most stress and anxiety? What is the origin and possible manifestation of professional stress in the cases of these professionals? How different is manifestation of stress experienced by pedagogues? These questions and other issues have structured the basis of the current paper.

The aim of the research is to reveal manifestation of stress and coping practised by teachers and specialists of educational support with regard to their professional experience.

The object of the research is manifestation of stress and coping in regard to professional experience.

\section{Methods and scope of the research}

In order to depict the peculiarities of stress experienced by pedagogues and specialists of educational support at work as well as its management strategies, an electronic questionnaire constituting from blocks of demographical questions and statements about possible educational situations has been created. Furthermore, the measurement scale by Lazarus (2006) CISS (Coping Inventory for Stressful Situations), adopted by Kriukova (2010) has been applied in the research. Its 48 statements have been divided regarding three factors: emotionoriented coping (EOC) with stress, task-oriented coping (TOC) with stress and avoidance-oriented (AOC) coping. The inner coherence of statements has been assessed at 0.081 .

The empirical data has been processed with SPSS-19 version applying descriptive analysis, Chi-square test and nonparametric tests (Mann-Whitney; Kruskal-Wallis) in order to actuate the management strategies with regard to professional experience of the recipients. Whilst examining hypothesis, statistically relevant coherence has been indicated in cases of assessment at 0.05 sharply or less.

The scope of the research was determined by target selection. 478 respondents (social, special and speech therapists and teachers from different regions of Lithuania) participated in the research. The scope of the research $(\mathrm{N}=478)$ is based on the data about the population of pedagogues provided by 
the Department of Statistics to the Government of Republic of Lithuania ${ }^{1}$ as well as scope calculator ${ }^{2}$ with bias of 5\% (Cekanavicius \& Murauskas, 2001; Kardelis, 2002).

\section{Manifestation of stress among pedagogues: analysis of research data}

The paper contains only a part of the research. It targets the stress the respondents encounter and the coping in respect to professional experience of the educators (record of service, category of qualification and professional field they work in).

Difference in rates of encountered stressful situations in respect to record of service. In order to determine the coherence between the record of service and encountered stressful situation, Chi-square test was applied with $\mathrm{p}<0.05$ as a level of significance. Statistically relevant difference has been observed in statements "you encounter indifference of your colleagues while dealing with problems" $\mathrm{x}^{2}=37.659, \mathrm{df}=24, \mathrm{p}=0.03$, and "you deal with children having behavioural problems" $\mathrm{x}^{2}=37.717, \mathrm{~d}=24, \mathrm{p}=0.03$ (Table 1 ).

The respondents were asked whether they often encounter indifference of their colleagues while dealing with problems. The results has shown that the majority of those with record of service shorter than 15 years encounter the indifference more often than the respondents with longer record of service $(p<0.05)$. Administration of educational institutions and other pedagogues expect a new employee to specialize in a new environment quickly and require assistance in its development quite fast. They expect new ideas and their realisation in the process of education. A conclusion may be drawn here that inexperienced teacher may not receive a proper assistance from experienced colleagues while facing a problem. Pedagogues with 20-year-record of service and longer state that they rarely or never encounter indifference of their colleagues while dealing with problems (Bubeliene, 2010; Klizas, Sulnienè, 2012).

Quite often stress may be induced by children with behavioural problems. The analysis of the empirical data has revealed that pedagogues with short record of service (less than 5 years) are more likely to deal with children having behavioural problems than more experienced colleagues with longer record of service $(\mathrm{p}<0.05)$.

\footnotetext{
${ }^{1}$ Department of Statistics to the Government of Republic of Lithuania

${ }^{2}$ The Survey system. http://www.surveysystem.com/sscalc.htm
} 
Table 1 Coherence between record of service and encountered stressful situations $(\mathrm{N}=478)$

\begin{tabular}{|c|c|c|c|c|c|c|c|}
\hline Statements & $\begin{array}{l}\text { Record } \\
\text { of } \\
\text { service }\end{array}$ & Never & Rarely & $\begin{array}{l}\text { Someti } \\
\text { mes }\end{array}$ & Often & $\begin{array}{l}\text { Very } \\
\text { often }\end{array}$ & $P \leq 0.05$ \\
\hline \multirow{7}{*}{$\begin{array}{l}\text { You encounter } \\
\text { indifference of } \\
\text { your colleagues } \\
\text { while dealing } \\
\text { with problems }\end{array}$} & $\begin{array}{l}\text { Less } \\
\text { than } 5 \\
\text { years }\end{array}$ & 27.7 & 31.9 & 25.5 & 6.4 & 8.5 & \multirow{7}{*}{0.03} \\
\hline & $5-10$ & 4.4 & 35.3 & 41,2 & 176 & 1.5 & \\
\hline & $10-15$ & 9.5 & 39,2 & 32.4 & 14.9 & 4.1 & \\
\hline & $15-20$ & $1 ., 7$ & 30,0 & 41.7 & 13.3 & 3.3 & \\
\hline & $20-25$ & $1 ., 2$ & 32,4 & 45.6 & 8.8 & 0 & \\
\hline & $25-30$ & 12.7 & 39,4 & 25.2 & 12.7 & 0 & \\
\hline & $\begin{array}{l}30 \text { and } \\
\text { more }\end{array}$ & 15.6 & 37,8 & 38.9 & 5.6 & 2.2 & \\
\hline \multirow{7}{*}{$\begin{array}{l}\text { You deal with } \\
\text { children having } \\
\text { behavioural } \\
\text { problems }\end{array}$} & $\begin{array}{l}\text { Less } \\
\text { than } 5 \\
\text { years }\end{array}$ & 0 & 2,1 & 25.5 & 29.8 & 42.6 & \multirow{7}{*}{0.03} \\
\hline & $5-10$ & 1.5 & 5,9 & 22.1 & 48.5 & 22.1 & \\
\hline & $10-15$ & 0 & 9,5 & 21.6 & 37.8 & 31.1 & \\
\hline & $15-20$ & 1.7 & 6,7 & 30.0 & 31.7 & 30.00 & \\
\hline & $20-25$ & 0 & 16,2 & 36.8 & 30.9 & 16.2 & \\
\hline & $25-30$ & 0 & 11,3 & 33.8 & 32.4 & 22.5 & \\
\hline & $\begin{array}{l}30 \text { and } \\
\text { more }\end{array}$ & 0 & 16,7 & 30.0 & 35.6 & 17.8 & \\
\hline
\end{tabular}

Manifestation of coping with regard to qualification category. In order to actuate the coping with regard to professional experience, i.e. considering the category of qualification as well as professional field, nonparametric tests have been applied.

In Lithuania, according to the certification conduct of teachers and specialists of educational support (social and special pedagogues, speech therapists) (2008), there are four qualification categories of teachers: a teacher, a senior teacher, a supervising teacher and an expert and respectively - four qualification categories for specialists of educational support. The researchers aimed at revealing statistically relevant differences in manifestation of coping with stress considering the qualification categories of the pedagogues 
Daiva Alifanoviene, Odeta Sapelyte, Rita Orska. Manifestation of Stress and Coping Concerning Professional Experience

Table 2 Manifestation of coping with stress regarding categories of professional qualification (Kruskall_Wallis test)

\begin{tabular}{|l|l|l|l|l|}
\hline Variables & $\begin{array}{l}\text { Pedagogues } \\
\text { / specialists } \\
\text { (N=119); } \\
\text { Mean } \\
\text { Rank }\end{array}$ & $\begin{array}{l}\text { Senior teachers/ } \\
\text { Senior specialists } \\
\text { (N=207); } \\
\text { Mean Rank }\end{array}$ & $\begin{array}{l}\text { Supervisors } \\
\text { and experts } \\
\text { (N=152); } \\
\text { Mean Rank }\end{array}$ & $\mathbf{p}^{3}$ \\
\hline I do shop browsing (AOC) & 270.76 & 224.80 & 235.05 & 0.006 \\
\hline $\begin{array}{l}\text { I recall the solutions of similar } \\
\text { problems from the past (TOA) }\end{array}$ & 277.00 & 222.42 & 233.40 & 0.001 \\
\hline $\begin{array}{l}\text { I try to see into the situation } \\
\text { (TOA) }\end{array}$ & 267.94 & 223.85 & 238.55 & 0.008 \\
\hline $\begin{array}{l}\text { I interact with someone I care } \\
\text { about (AOC) }\end{array}$ & 275.41 & 233.22 & 219.94 & 0.002 \\
\hline I go for a walk (AOC) & 264.18 & 235.59 & 225.50 & 0.053 \\
\hline $\begin{array}{l}\text { I consult somebody whose } \\
\text { advice I take into account } \\
\text { (AOC) }\end{array}$ & 272.05 & 230.12 & 226.80 & 0.007 \\
\hline $\begin{array}{l}\text { I depict priorities of the present } \\
\text { situation (TOA) }\end{array}$ & 239.28 & 223.79 & 261.07 & 0.022 \\
\hline I watch TV (AOC) & 221.33 & 235.71 & 258.89 & 0.059 \\
\hline
\end{tabular}

The analysis of the empirical data concerning categories of professional qualification has proven that retreat and avoidance are more common among the pedagogues with lower qualification category, in comparison to those with higher qualification. Statistically relevant difference has been noticed comparing pedagogues or specialists with lowest qualification category to supervising teachers and experts, e.g. I interact with someone I care about $(p=0.002) ;$ I go for a walk ( $p=0.053)$; I consult somebody whose advice I take into account $(p=0.007)$. It should be emphasised that qualification category involves practical skills, knowledge and personal abilities. Therefore, the lower the qualification category, the scarcer practical skills, knowledge or personal abilities are. The lack of practical skills or knowledge in particular may decide the choice of retreat while facing difficult or stressful situations. The situation may also be influenced by scarcity of personal or social maturity. Compas, Orosan \& Grant (1993) have emphasised that elder persons tend to practice strategies of copying with difficulties rather than choose emotional reaction to a particular situation or use strategy of retreat. They also are more inclined to analyse a particular situation, search for different solutions of a problem and implement the sequence of actions they decide on. Here also should be noted that in some cases

\footnotetext{
${ }^{3} p<0.05$
} 
less-experienced pedagogues are those that tend to practise problem-oriented coping strategies more willingly than supervising teachers (I recall the solutions of similar problems from the past, $p=0.001 ;$ I try to see into the situation $(p=0.008)$.

\section{Manifestation of coping with regards to professional field.}

The way teachers and specialists of educational support cope with stressful situations has also been considered including the strategies they choose for stress management. 336 subject and class teachers as well as 142 specialists of educational support (speech therapists, social workers, special pedagogues), who are responsible for providing participants of educational process with educational support and coordination, took part in the research. Table 3 illustrates manifestation of stress management strategies with regard to professional field of the respondents.

Table 3 Manifestation of coping

\begin{tabular}{|c|c|c|c|c|}
\hline $\begin{array}{l}\text { Stress management } \\
\text { strategies }\end{array}$ & $\begin{array}{l}\text { Pedagogues } \\
(\mathrm{N}=336) \\
\text { Mean Rank }\end{array}$ & $\begin{array}{l}\text { Specialists of } \\
\text { educational support } \\
(\mathrm{N}=142) \text {, Mean Rank }\end{array}$ & \multicolumn{2}{|c|}{ Statistical data } \\
\hline \multirow{4}{*}{$\begin{array}{l}\text { I do shop browsing } \\
\text { (AOC) }\end{array}$} & \multirow{4}{*}{226.18} & \multirow{4}{*}{271.01} & 19381.500 & $\mathrm{U}^{4}$ \\
\hline & & & 75997.500 & $\mathrm{~W}^{5}$ \\
\hline & & & -3.548 & $\mathrm{Z}$ \\
\hline & & & 0.000 & $p^{6}$ \\
\hline \multirow{4}{*}{$\begin{array}{l}\text { I recall the solutions } \\
\text { of similar problems } \\
\text { from the past (TOC) }\end{array}$} & \multirow{4}{*}{224.30} & \multirow{4}{*}{275.46} & 18749.000 & $\mathrm{U}$ \\
\hline & & & 75365.000 & $\mathrm{~W}$ \\
\hline & & & -3.951 & $\mathrm{Z}$ \\
\hline & & & 0.000 & $\mathrm{p}$ \\
\hline \multirow{4}{*}{$\begin{array}{l}\text { I convince myself that } \\
\text { this is not happening } \\
\text { to me (EOC) }\end{array}$} & \multirow{4}{*}{230.93} & \multirow{4}{*}{259.79} & 20975,500 & $\mathrm{U}$ \\
\hline & & & 77591.500 & $\mathrm{~W}$ \\
\hline & & & -2.285 & $\mathrm{Z}$ \\
\hline & & & 0.022 & $\mathrm{p}$ \\
\hline \multirow{4}{*}{$\begin{array}{l}\text { I blame myself for } \\
\text { irrational emotionality } \\
\text { in a given situation } \\
(\text { EOC) }\end{array}$} & \multirow{4}{*}{248.01} & \multirow{4}{*}{219.37} & 20998.000 & $\mathrm{U}$ \\
\hline & & & 31151.000 & $\mathrm{~W}$ \\
\hline & & & -2.173 & $\mathrm{Z}$ \\
\hline & & & 0.030 & $\mathrm{p}$ \\
\hline \multirow{4}{*}{$\begin{array}{l}\text { I have a lunch break } \\
\text { or a snack (AOC) }\end{array}$} & \multirow{4}{*}{230.32} & \multirow{4}{*}{261.21} & 20772.500 & $\mathrm{U}$ \\
\hline & & & 77388.500 & $\mathrm{~W}$ \\
\hline & & & -2.353 & $\mathrm{Z}$ \\
\hline & & & 0.019 & $\mathrm{p}$ \\
\hline
\end{tabular}

\footnotetext{
${ }^{4}$ Mann-Whitney U

${ }^{5}$ Wilcoxon W

${ }^{6}$ Asymp. Sig., $\mathrm{p}<0.05$
} 
Daiva Alifanoviene, Odeta Sapelyte, Rita Orska. Manifestation of Stress and Coping Concerning Professional Experience

\begin{tabular}{|c|c|c|c|c|}
\hline \multirow{4}{*}{$\begin{array}{l}\text { I buy something for } \\
\text { myself (AOC) }\end{array}$} & \multirow{4}{*}{229.37} & \multirow{4}{*}{263.48} & 20451.500 & $\mathrm{U}$ \\
\hline & & & 77067.500 & $\mathrm{~W}$ \\
\hline & & & -2.597 & $\mathrm{Z}$ \\
\hline & & & 0.009 & $\mathrm{p}$ \\
\hline \multirow{4}{*}{$\begin{array}{l}\text { I make a plan for } \\
\text { acting and keep to it } \\
\text { (TOC) }\end{array}$} & \multirow{4}{*}{231.48} & \multirow{4}{*}{258.47} & 21162.000 & $\mathrm{U}$ \\
\hline & & & 77778.000 & $\mathrm{~W}$ \\
\hline & & & -2.083 & $\mathrm{Z}$ \\
\hline & & & $\mathbf{0 . 0 3 7}$ & $\mathrm{p}$ \\
\hline \multirow{4}{*}{$\begin{array}{l}\text { I go to a party, visit } \\
\text { my friends (AOC) }\end{array}$} & \multirow{4}{*}{230.92} & \multirow{4}{*}{259.79} & 20974.500 & $\mathrm{U}$ \\
\hline & & & 77590.500 & $\mathrm{~W}$ \\
\hline & & & -2.207 & $\bar{Z}$ \\
\hline & & &, $\mathbf{0 2 7}$ & $\mathrm{p}$ \\
\hline \multirow{4}{*}{$\begin{array}{l}\text { I consult somebody } \\
\text { whose advice I take } \\
\text { into account (AOC) }\end{array}$} & \multirow{4}{*}{229.54} & \multirow{4}{*}{263.07} & 20509.000 & $\mathrm{U}$ \\
\hline & & & 77125.000 & $\mathrm{~W}$ \\
\hline & & & -2.572 & $\mathrm{Z}$ \\
\hline & & &, 010 & $\mathrm{p}$ \\
\hline \multirow{4}{*}{$\begin{array}{l}\text { I analyse the situation } \\
\text { before reacting to it } \\
\text { (TOC) }\end{array}$} & \multirow{4}{*}{231.50} & \multirow{4}{*}{258.42} & 21169.500 & $\mathrm{U}$ \\
\hline & & & 77785.500 & $\mathrm{~W}$ \\
\hline & & & -2.057 & $\mathrm{Z}$ \\
\hline & & & ,040 & $\mathrm{p}$ \\
\hline \multirow{4}{*}{$\begin{array}{l}\text { I call my friends } \\
(\mathrm{AOC})\end{array}$} & \multirow{4}{*}{225.50} & \multirow{4}{*}{272.50} & 19169.500 & $\mathrm{U}$ \\
\hline & & & 75785.500 & $\mathrm{~W}$ \\
\hline & & & -3.499 & $\mathrm{Z}$ \\
\hline & & & ,000 & $\mathrm{p}$ \\
\hline \multirow{4}{*}{$\begin{array}{l}\text { I think of several } \\
\text { possible solutions of } \\
\text { the problem (TOC) }\end{array}$} & \multirow{4}{*}{231.63} & \multirow{4}{*}{258.13} & 21210.500 & $\mathrm{U}$ \\
\hline & & & 77826.500 & $\mathrm{~W}$ \\
\hline & & & -2.060 & $\mathrm{Z}$ \\
\hline & & & 0.039 & $\mathrm{p}$ \\
\hline \multirow{4}{*}{$\begin{array}{l}\text { I try to concentrate in } \\
\text { order to succeed in a } \\
\text { given situation (TOC) }\end{array}$} & \multirow{4}{*}{230.10} & \multirow{4}{*}{261.73} & 20699.000 & $\mathrm{U}$ \\
\hline & & & 77315.000 & $\mathrm{~W}$ \\
\hline & & & -2.442 & $\mathrm{Z}$ \\
\hline & & & 0.015 & $\mathrm{p}$ \\
\hline \multirow{4}{*}{ I watch TV (AOC) } & \multirow{4}{*}{249.66} & \multirow{4}{*}{215.46} & 20442.500 & $\mathrm{U}$ \\
\hline & & & 30595.500 & $\mathrm{~W}$ \\
\hline & & & -2.577 & $\mathrm{Z}$ \\
\hline & & & 0.010 & $\mathrm{p}$ \\
\hline
\end{tabular}

The empirical data calls for explanation of the paradox. In fact, rather contradictory trends have been noticed while trying to indicate statistically relevant diversity in strategizing stress management among different professionals (teachers and specialists of educational support in this case) which needs to be discussed. The analysis of the research data has indicated that diversity of coping may be noticed in 14 cases (48 statements each, see Table 3 ). For the most part, statistically relevant data may be observed on the scale of retreat. In fact, more often than teachers, specialists of educational support tend 
to retreat from a stressful situation rather than see into a given problem (e.g. I do shop browsing $(\mathrm{U}=19381.500$; Wilcoxon $\mathrm{W}=75997.500 ; \mathrm{p}=0.000)$; I have a lunch break or a snack ( $U=20772.500$; Wilcoxon $\mathrm{W}=77388.500 ; \mathrm{p}=0.019 ; \mathrm{I}$ call my friends $(\mathrm{U}=19169.500$; Wilcoxon $\mathrm{W}=75785.500, \mathrm{p}=0.000)$ etc. $)$. This may be due to the fact that work of a specialist of educational support is not defined properly, work of social pedagogues in particular. Unforeseen events and complicated circumstances (such as cases of violence, bullying at school, interaction crisis, etc.), which require a decisive mind, individual solution for a given problem in order to balance needs and expectations of those participating in educational process, are highly likely to appear on their daily schedule. Providing support for children and their environment is a prolonged process requiring both participation and cooperation of all parties involved. Constantly, parents and other educators expect instant results. Therefore, in case of uncertainty or controversy between needs and expectations, strategies of retreat or avoidance are observed at work. While investigating stress in teachers' work, Bulotaite \& Lepeskiene (2006) have noted that decisions to avoid stressful situations are more common when discontent with educator's position rise on general. The paradox lies in the fact that during the process of training specialists of educational support are prepared for working in complicated circumstances requiring an integrated scheme of solutions. Specialists of educational support are expected to apply strategies of task-oriented strategies as their work involves abilities and possibilities to meet the needs of participants of educational processes and solve complicated issues encountered. The present controversy may also be confirmed by the statements related to problem-solving activities as specialists of educational support are more likely to practice them than teachers (e. g. I think of several possible solutions of the problem $(\mathrm{p}=0.039)$; I try to concentrate in order to succeed in a given situation $(\mathrm{p}=0.015)$. However, avoidance-oriented strategies including retreat are more often exercised by specialists of educational support.

\section{Conclusions}

- Stress experienced by professionals has been investigated by scientists from different fields such as pedagogics, psychology, biomedicine or management. Due to new technologies of information and communication as well as intense way of life in all spheres (including educational system) dramatic changes of events have emerged. The reorganization of Lithuanian educational system throughout the last decade has introduced many changes, uncertainty, anxiety, frustration and stress which can hardly be counterbalanced by social welfare among the participants of the educational processes. In the context of social change and educational 
reforms, educators have to work under pressure of constant instability, which as well as perpetual challenging affects working results, quality and efficiency of professional educators.

- Indifference shown by colleagues and work with children having behavioural difficulties are regarded as inducing stress. Statistical correlation between a record of educational service and aforementioned resources of stress has been noted.

- nonparametric tests have been applied in order to actuate the coping with regard to professional experience. Considering the category of qualification, there should be noted that teachers and specialists with lower qualification category and therefore lacking practical skills and knowledge tend to apply avoidance-oriented strategies and retreat more often than pedagogues with higher professional category of qualification.

- A rather gripping and contradictory trend has to be noted regarding particularities of professional matter. Despite the fact that specialists of educational support are trained to search for rational decisions ensuring coherence in needs of all participants of the process as well as meeting their requirements, the specialists tend to apply avoidance-oriented strategies with retreat more often than subject teachers.

\section{References}

Alifanovienė, D., \& Vaitkevičienė, A. (2012). Socialinių darbuotojų ir socialinių pedagogų išgyvenamo nerimo ypatumų analizè: specialistų nuomonès aspektas. Tiltai, 4, 135-149.

Bandzienè, A. (2009). Kompleksinis streso darbe valdymas. Daktaro disertacija. ISM Vadybos ir ekonomikos universitetas.

Bubelienè, D. (2010). Mokytoju profesinis stresas ir jo redukavimo prielaidos švietimo vadybos bei edukacinèmis priemonemis. Daktaro disertacija. Šiaulių universitetas

Bubelienè, D., \& Merkys, G. (2012). Pedagogu streso socialinis konstravimas ir jo atspindžiai profesineje spaudoje. Acta Paedagogica Vilnensia, 29, 100-110

Bulotaitè, L., \& Lepeškienė, V. (2006). Mokytojų stresas ir jo įveikimo strategijos. Pedagogika, 84, 48-51.

Bulotaite, L., Pociūtè, B., \& Bliumas, R. (2008). Universiteto dèstytojų darbo ir streso ypatumai. Acta Paedagogica Vilnensia, 21, 208-219.

Bulotaitè, L., \& Lepeškienè, V. (2006). Mokytojų stresas ir jo įveikimo strategijos. Pedagogika, 84, 48-51.

Colman, A.M. (2015). A Dictionary of Psychology (4 ed.). Oxford University Press. Retrieved from: http://www.oxfordreference.com/view/10.1093/acref/9780199657681.001.0001/ acref-9780199657681-e-8038?rskey $=U$ XgrMF\&result $=8517$

Compas, B. E., Orosan, P. G., \& Grant, K. E. (1993). Adolescent stress and coping: implications for psychopathology during adolescence. Journal of Adolescence, 16 , 331-349.

Čekanavicius, V., \& Murauskas, G. (2001). Statistika ir jos taikymas. TEV Vilnius. 
European Foundation for the Improvement of Living and Working Conditions (2010). Workrelated stress. Retrieved from: http://www.eurofound.europa.eu/sites/default/files/ ef_files/docs/ewco/tn1004059s/tn1004059s.pdf

Goštautas, A. (1999). Psichologiniai streso aspektai. Sveikata, 6, 55-58.

Grakauskas, Ž. (2004). Stresas ir elgesio savireguliacija: teorinès sąveikos problemos. Psichologija: mokslo darbai, 29, 74-87.

Grakauskas, Ž., \& Valickas, G. (2006). Streso įveikos klausimynas: keturių faktorių modelio taikymas. Psichologija, 33, 64-75

Kardelis, K. (2002). Moksliniu tyrimu metodologija ir metodai. 2-asis leidimas. Šiualiai.

Keturakis, V. (1998). Nuo psichologinio streso iki emocijų: besikeičiančių požiūrių istorija. Psichologija, 18, 124-141.

Kepalaitè, A. (2013a). Socialinių pedagogų streso ir jo įveikos strategijų sąsajos. Ugdymo psichologija, 24, 27-34.

Kepalaitè, A. (2013b). Socialinès pedagogikos pirmo kurso studentų streso įveikos ypatumai. Specialusis ugdymas, 2 (29), 94-100

Klizas, Š., \& Šulnienè, R. (2012). Stresas pedagogų darbe priklausomai nuo ugdymo įstaigos. Sveikatos mokslai, 22,(5), 5-8.

Kriukova, T.L. (2010). Методы изучения совладающего поведения: три копинг-шкальь [Methods of coping research: three coping scales]. Kostroma.

Lazarus, R.S. (2006). Stress and Emotion: A New Synthesis. New York: Springer Publishing Company.

Pikūnas, J., \& Palujanskienè, A. (2005). Stresas. Atpažinimas ir żveikimas. Kaunas: Pasaulio lietuviu centras

Report of European Trade Union Committee for Education. (2011). ETUCE.

Valickas, G., Grakauskas, Ž., \& Želvienė, P. (2010). Patobulinto keturių faktorių streso iveikos klausimyno psichometriniai rodikliai. Psichologija, 41, 96-110. 